\title{
EFEKTIVITAS AIR CUCIAN BERAS DAN AIR RENDAMAN CANGKANG TELUR PADA BIBIT ANGGREK Dendrobium
}

\section{THE EFFECTIVENESS OF RICE-WASHED WATER AND EGGSHELL IMMERSION WATER IN Dendrobium ORCHID SEEDLINGS}

\author{
Tini Sudartini ${ }^{*}$, Fitri Kurniati dan Ade Nining Lisnawati \\ Jurusan Agroteknologi Fakul tas Pertanian Universitas Siliwangi \\ Jl. Siliwangi No. 24PO Box 164 Tasikmalaya 46115 \\ Korespondensi : tinisudartini@yahoo.com
}

Diterima: 10 Oktober 2017/ Disetujui 19 November 2018

\begin{abstract}
ABSTRAK
Air cucian beras masih mengandung karbohidrat cukup tinggi yang berasal dari kulit ari beras yang terkelupas. Disamping itu, air cucian beras mengandung nitrogen, fosfor, kalium, magnesium, sulfur, besi dan vitamin B1 yang dibutuhkan untuk pertumbuhan tanaman. Cangkang telur juga mengandung fosfor, magnesium, kalium, seng mangan dan besi yang merupakan unsur hara penting bagi tanaman. Percobaan dilaksanakan di kebun percobaan Fakultas Pertanian Universitas Siliwangi Tasikmalaya. Waktu percobaan dimulai pada bulan Februari sampai bulan September 2017. Metode penelitian yang digunakan adalah metode eksperimen dengan menggunakan desain Rancangan Acak Kelompok terdiri dari 8 perlakuan dan diulang sebanyak tiga kali. Perlakuan yaitu: tanpa aplikasi/kontrol, aplikasi pupuk daun lengkap Gandasil D 10 hari satu kali, aplikasi air cucian beras 3 hari satu kali, aplikasi air cucian beras 5 hari satu kali, aplikasi air cucian beras 7 hari satu kali, aplikasi air rendaman cangkang telur 3 hari satu kali, aplikasi air rendaman cangkang telur 5 hari satu kali, aplikasi air rendaman cangkang telur 7 hari satu kali. Air cucian beras dan air rendaman cangkang telur yang diaplikasikan pada 3, 5 dan 7 hari satu kali belum efektif terhadap peningkatan tinggi tanaman, jumlah daun, luas daun, dan bobot brangkasan segar tanaman sampai umur 84 HST.
\end{abstract}

Kata Kunci : air cucian beras, bibit anggrek Dendrobium, cangkang telur, pupuk organik

\begin{abstract}
Rice-washed water contains quite high carbohydrates from the peeled seeds epidermis. It also contains nitrogen, phosphorus, potassium, magnesium, sulfur, iron, and vitamin B1 needed for plant growth. Eggshells contain phosphorus, magnesium, potassium, zinc manganese and iron, which are essential elements for plants. The experiment was conducte $d$ at the experimental field of the Faculty of Agriculture, Siliwangi University, Tasikmalaya. The experiment started from February 2017 to September 2017. The research method used Randomized Block Design consists of eight treatments and three replications. The treatments are without application/control, complete application of Gandasil D fertilizer once in ten days,
\end{abstract}

Cyte this as: Sudartini, T., Kurniati, F \& Lisnawati, A, N. (2020). Efektivitas air cucian beras dan air rendaman cangkang telur pada bibit anggrek dendrobium. Jurnal Agro, 7(1), 82-91. https://doi.org/10.15575/1676 
rice-washed water application once in three days, rice-washed water application once in five days, rice-washed water application once in seven days, eggshells immersion water application once in three days, eggshell immersion water application once in five days, and eggshell immersion application once in seven days. The application of rice-washed water and eggshell immersion water, which was applied at once in 3, 5 and 7 days, had not been affected to plant height, the number of leaves, leaf area, and fresh weight of plant stover until 84 days after planting.

Keywords: Dendrobium orchid seeds, eggshell, organic fertilizer, rice-washed water

\section{PENDAHULUAN}

Tanaman hortikultura berfungsi bukan hanya untuk memenuhi kesehatan fisik yang disebabkan kandungan vitamin, mineral dan protein yang berasal dari tanaman sayur dan buah, juga memenuhi kebutuhan kenyamanan, keindahan yang diperoleh karena bentuk warna dan corak tanaman hias. Salah satu tanaman hias yang populer di Indonesia ialah tanaman anggrek yang dinikmati melalui keindahan bunganya. Bunga anggrek dimanfaatkan tidak hanya untuk tanaman hias di ru mah rumah, melainkan juga dipergunakan sebagai tanaman rental untuk perkantoran atau komponen taman pada landscape modern.

Menurut Novianto (2012), ditengah pertumbuhan ekonomi dan maraknya lalu lintas tranksaksi perdagangan nasional saat ini, anggrek hadir dan menempatkan diri pada posisi yang makin terhormat dalam daftar belanja kaum menengah. Peningkatan ekonomi dan kesejahteraan nasional membuat kebutuhan akan kepuasan estetika menjadi bagian dari gaya hidup sehari-hari, dan anggrek menjadi salah satu primadona pemenuhan kebutuhan ini. Hal ini menyebabkan permintaan anggrek terus meningkat. Akibatnya peningkatan kapasitas dan kualitas produksi oleh produsen anggrek juga perlu ditingkatkan.
Menurut Balai Penelitian Tanaman Hias (2012) salah satu jenis anggrek yang sangat populer di Indonesia yaitu anggrek Dendrobium, karena produksi bunga tinggi, warna bunga sangat bervariasi, bentuk bunga menarik, mahkota bunga kompak, tekstur bunga tebal dan tahan lama sebagai bunga potong, tangkai panjang, mudah tumbuh dan mudah perawatannya. Menurut Hartati et al. (2014) persilangan tanaman anggrek bertujuan untuk mendapatkan varietas baru dengan warna dan bentuk yang menarik dan beragam. Menurut Sari et al. (2015), perkembangan produksi anggrek saat ini masih relatif lambat, sementara permintaan pasar anggrek semakin meningkat setiap tahunnya. Dendrobium merupakan salah satu genus anggrek paling komersial yang memiliki pangsa pasar sekitar 50 persen dari total pangsa pasar anggrek.

Berdasarkan data statistik tanaman hias dari Badan Pusat Statistik (2017) produksi tanaman bunga potong anggrek pada tahun 2017 sebanyak 20 juta tangkai. Proyeksi produksi pada tahun 2019 akan mencapai 23,68 juta tangkai, lebih kecil dari sasaran renstra yaitu 28,00 juta tangkai atau selisih 2.32 juta tangkai $(8,94$ \%). Gambaran di atas mencerminkan adanya selisih antara permintaan dan produksi anggrek. Menurut Herwati (2015) meningkatnya permintaan pasar akan 
anggrek dalam bentuk bunga potong dan tanaman pot, maka diperlukan usaha peningkatan kualitas dan kuantitas penyediaan anggrek dalam jumlah lebih banyak dan berkesinambungan.

Peningkatan kuantitas tanaman anggrek Dendrobium harus diawali dengan penyediaan bibit anggrek yang bermutu tinggi. Seedling anggrek yang berkualitas akan menghasilkan bunga dengan baik. Ciri-ciri seedling anggrek Dendrobium yang baik yaitu batang kuat, dan subur. Tanaman anggrek termasuk tanaman yang mempunyai kecepatan tumbuh yang lambat. Oleh karena itu sangat diperl ukan penambahan unsur hara secara terus menerus sepanjang pertumbuhannya. Menurut Dewi \& Setiawati (2010) tanaman anggrek memiliki pertumbuh lambat. Konsentrasi pupuk yang rendah dengan frekuensi pemupukan yang sering dapat dijadikan alternatif untuk meningkatkan pertumbuhan anggrek.

Menurut

Dwiyani

penyemprotan pupuk daun dengan frekuensi yang jarang tidak akan efektif, sedangkan penyemprotan pupuk daun terlalu sering dapat menghambat pertumbuhan tanaman.

Menurut Citra (2012) air limbah cucian beras yang dihasilkan ketika membersihkan beras dibuang begitu saja. Air cucian beras sebenarnya tidak membahayakan untuk kesehatan, akan tetapi dapat mencemari air bersih. Saat ini, limbah air cucian beras belum dimanfaatkan secara optimal. Padahal, air cucian beras mengandung karbohidrat cukup tinggi berasal dari kulit ari beras yang terkelupas. Air limbah cucian beras sudah dibuktikan manfaatnya untuk menyuburkan tanaman secara empiris dari generasi ke generasi, kandungan senyawa organik dan mineral yang dimiliki sangat beragam, antara lain karbohidrat, nitrogen, fosfor, kalium, magnesium, sulfur, besi dan vitamin B1. Menurut Akib et al. (2014), air limbah cucian beras dapat meningkatkan pertumbuhan tanaman karena masih mengandung karbohidrat (pati), Glutein, selulose, hemi selulose protein, thiamin (B1), P dan Fe.

Selain air cucian beras, limbah yang belum dimanfaatkan yaitu cangkang tel ur. Menurut Sari et al. (2015) konsumsi telur di Indonesia akan terus berlimpah selama telur diproduksi dibidang peternakan, telur-telur tersebut digunakan untuk keperluan di restoran, usaha rumahan kue kering, pabrik roti dan mie, serta para pedagang kaki lima yang menjajakan martabak telur sebagai bahan baku pembuatan makanan. Telur yang sudah diolah menjadi bahan makanan, cangkang atau kulit telurnya tentu sudah tidak terpakai lagi. Menurut Gongruttananun (2011) cangkang telur memilikikandungan unsur kalsium dan unsur lainnya yang dapat dimanfaatkan.

Media tanam yang dicampur dengan pecahan cangkang telur, menyediakan unsur hara yang berguna untuk pertumbuhan dan perkembangan tanaman, begitu pula air rendaman cangkang telur. Kualitas cangkang telur mengandung 2,2 g kalsium dalam bentuk calcium carbonat $\left(\mathrm{CaCO}_{3}\right)$. Sekitar $95 \%$ dari berat cangkang telur adalah 5,5 g $\mathrm{CaCO}_{3}$. Rata-rata cangkang telur mengandung sekitar 3\% fosfor, $3 \%$ magnesium dan elemen penting natrium, kalium, seng, mangan dan besi. Menurut Nikose (2015) cangkang telur kaya akan sumber kalsium dan dapat digunakan sebagai sumber pupuk organik. Perendaman cangkang telur dalam air 
akan melepaskan kandungannya keluar dan pindah ke air perendamnya. Fungsi kalsium adalah mendorong pembentukan dan pertumbuhan akar lebih dini, memperbaiki ketegaran tanaman, mempengaruhi pengangkutan air dan unsur-unsur hara, diperlukan untuk pemanjangan sel-sel, sintesis protein, pembelahan sel, dan mengatur translokasi karbohidrat.

Hasil penelitian Wardiah \& Rahmatan (2014) tanaman yang pakcoi yang diberi air cucian beras dengan konsentrasi 100\% dapat meningkatkan pertumbuhan tanaman. Penggunaan air limbah cucian beras dan air rendaman cangkang telur sebagai pupuk untuk tanaman anggrek dapat membantu masyarakat dalam melakukan budidaya tanaman anggrek dengan biaya produksi yang relatif rendah, namun dapat mendorong pertumbuhan tanaman dengan baik. Berdasarkan uraian di atas, penulis melakukan penelitian tentang efektivitas air cucian beras dan air rendaman cangkang telur untuk meningkatkan pertumbuhan fase bibit anggrek Dendrobium

\section{BAHAN DAN METODE}

Penelitian dilaksanakan di kebun percobaan Fakultas Pertanian Universitas Siliwangi Tasikmalaya. Waktu percobaan dimulai pada pertengahan bulan Februari sampai dengan bulan September 2017, menggunakan metode experimen rancangan acak kelompok (RAK) dengan 8 perlakukan sebagai berikut: kontrol tanpa aplikasi (A), pupuk daun lengkap 10 hari satu kali (B), aplikasi cucian beras 3 hari satu kali (C), aplikasi air cucian beras 5 hari satu kali (D) , aplikasi air cucian beras 7 hari satu kali (E), aplikasi air rendaman cangkang telur 3 hari satu kali (F), aplikasi air rendaman cangkang telur 5 hari satu kali (G), aplikasi air rendaman cangkang telur 7 hari satu kali (h). Kedelapan perlakuan diulang 3 kali sehingga terdapat 24 petak. Variabel respon yang diamati yaitu : tinggi tanaman, jumlah daun,luas daun dan bobot brangkasan segar per tanaman. Rancangan analisis dengan dengan uji F. Pengambilan keputusan berdasarkan nilai $F$ hitung dibandingkan dengan nilai $\mathrm{F}$ tabel. Bila $\mathrm{F}$ hitung $\leq \mathrm{F}$ tabel berarti tidak ada pengaruh perlakuan. Bila $\mathrm{F}$ hitung > F tabel berarti terdapat pengaruh perlakuan yang dicoba. Untuk mengetahui perlakuan yang berpengaruh paling baik maka diuji dengan Uji Jarak Berganda Duncan pada taraf $5 \%$.

Obyek penelitian berupa bibit anggre $k$ Dendrobium (Indonesia emas / Sianne velvet) $x$ (Black spider /Lasianthera yang mempunyai kriteria seperti yang terdapat pada Tabel 1.

Tabel 1. Kriteria bibit anggrek Dendrobium

\begin{tabular}{lcc}
\hline \multicolumn{1}{c}{ Kriteria } & Rata -rata & Ragam \\
\hline bobot brangkasan/(g) & 1,187 & 0,024 \\
tinggi tanamam (cm) & 8,342 & 0,304 \\
Jumlah daun (helai ) & 4,292 & 0,176 \\
\hline
\end{tabular}

Satu perlakuan terdiri dari 15 bibit (15 pot tunggal), sehingga keseluruhannya diperlukan 400 bibit anggrek termasuk cadangan perlakuan.

Pembuatan air cucian beras dibuat dengan perbandingan beras dan air untuk mencuci beras yaitu $1: 2$ atau $100 \mathrm{~g}$ beras dilarutkan dengan $200 \mathrm{ml}$ air. Beras direndam lalu remas-remas halus sebanyak 5 kali. Kemudian sisa air cucian beras pertama ditampung kemudian disaring selanjutnya akan difermentasi dengan EM 4 selama 6 hari. EM 4 
mengandung bakteri bakteri fotosintetik Lactobacillus,sp, Saccharomyces, sp, Actino-mycetes, sp dan jamur fermentasi. Penambahan EM-4 dimaksudkan untuk proses fermentasi dan dekomposisi bahan organik air beras. Fermentasi 6 hari dapat meningkatkan kandungan fosfor dan sulfur dan nitrogen (Akib et al., 2014). Cara membuat air rendaman cangkang telur yaitu merebus air sebanyak satu liter sampai mendidih $\left(80^{\circ} \mathrm{C}\right)$, kemudian ditambahkan sebanyak 8 cangkang telur yang telah diremukan ke dalamnya. Cangkang telur direndam cangkang telur selama 24 jam, kemudian air diaduk rata. Cairan cangkang telur siap digunakan untuk pupuk daun. Pembuatan larutan pupuk daun lengkap yaitu dengan cara melarutkan sebanyak $3 g$ pupuk Gandasil D kedalam air sebanyak satu liter air. Aplikasinya satu kali setiap sepuluh hari.

\section{HASIL DAN PEMBAHASAN}

\section{Pengamatan Utama}

Pertumbuhan tinggi bibit mulai umur 42 HST sampai dengan umur 84 HST pada umumnya mengalami kenaikan secara normal pada semua perlakuan (Gambar 1).

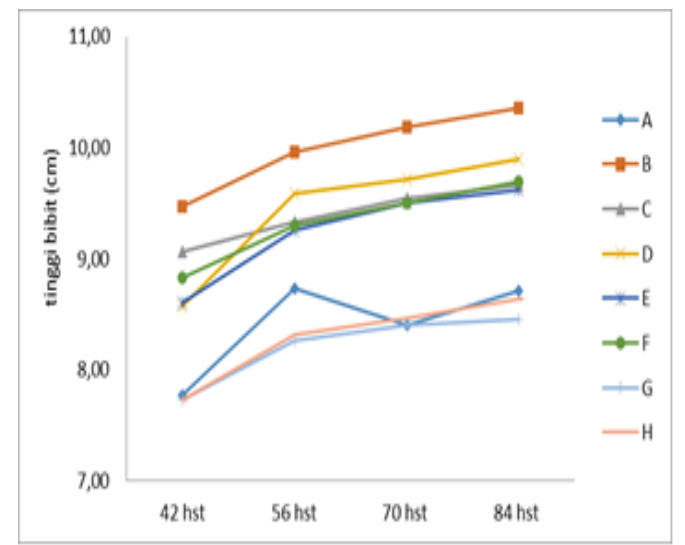

Gambar 1. Grafik Pertumbuhan tinggi tanaman

Berdasarkan hasil analisis statistik, diketahui bahwa berbagai frekuensi aplikasi air cucian beras dan air rendaman cangkang telur berpengaruh tidak nyata terhadap tinggi bibit (Tabel 2). Pada semua umur pengamatan tinggi bibit memiliki nilai rata-rata yang lebih rendah pada perlakuan kontrol, aplikasi air rendaman cangkang telur 5 dan 7 hari satu kali. Sedangkan pada perlakuan aplikasi pupuk daun lengkap sepuluh hari satu kali, air cucian beras 3, 5 dan 7 hari sekali serta aplikasi rendaman cangkang telur 3 hari satu kali menunjukkan nilai rata-rata yang lebih tinggi.

Tabel 2. Pengaruh frekuensi aplikasi air cucian beras dan rendaman cangkang telur terhadap tinggi bibit $(\mathrm{cm})$

\begin{tabular}{lcccc}
\hline & \multicolumn{4}{c}{ Tinggi tanaman $(\mathrm{cm})$} \\
\multicolumn{1}{c}{ Perlakuan } & 42 & 56 & 70 & 84 \\
& HST & HST & HST & HST \\
\hline A (kontrol /tanpa aplikasi) & 7,77 a & 8,73 a & 8,40 a & $8,71 \mathrm{a}$ \\
B (pupuk daun lengkap 10 hari satu kali) & $9,47 \mathrm{a}$ & $9,96 \mathrm{a}$ & $10,18 \mathrm{a}$ & $10,36 \mathrm{a}$ \\
C (aplikasi air cucian beras 3 hari satu kali) & $9,06 \mathrm{a}$ & $9,33 \mathrm{a}$ & $9,54 \mathrm{a}$ & $9,66 \mathrm{a}$ \\
D (aplikasi air cucian beras 5 hari satu kali) & $8,57 \mathrm{a}$ & $9,59 \mathrm{a}$ & $9,72 \mathrm{a}$ & $9,90 \mathrm{a}$ \\
E (aplikasi air cucian beras 7 hari satu kali) & $8,60 \mathrm{a}$ & $9,26 \mathrm{a}$ & $9,50 \mathrm{a}$ & $9,62 \mathrm{a}$ \\
F (aplikasi air rendaman cangkang telur 3 hari satu kali) & $8,83 \mathrm{a}$ & $9,30 \mathrm{a}$ & $9,50 \mathrm{a}$ & $9,69 \mathrm{a}$ \\
G (aplikasi air rendaman cangkang telur 5 hari satu kali) & $7,73 \mathrm{a}$ & $8,26 \mathrm{a}$ & $8,40 \mathrm{a}$ & $8,46 \mathrm{a}$ \\
H (aplikasi air rendaman cangkang telur 7 hari satu kali) & $7,73 \mathrm{a}$ & $8,32 \mathrm{a}$ & $8,47 \mathrm{a}$ & $8,64 \mathrm{a}$ \\
\hline
\end{tabular}

Keterangan : Angka-angka yang diikuti oleh huruf yang sama tidak berbeda nyata menurut uji Jarak Berganda Duncan pada taraf nyata $5 \%$ 
Tabel 3 di bawah ini menyajikan pengaruh frekuensi aplikasi air cucian beras terhadap jumlah daun pada umur 42 HST sampai dengan 84 HST. Jumlah daun pada umur 42 HST, tidak berbeda nyata pada semua perlakuan demikian pula pada umur 56, 70 dan $84 \mathrm{HST}$.

Secara umum terlihat nilai rata rata jumlah daun lebih sedikit pada perlakuan kontrol dan aplikasi rendaman cangkang telur 7 hari satu kali. Pada perlakuan pupuk daun lengkap, aplikasi air cucian beras 3,5 dan 7 hari satu kali, nilai ratarata jumlah daun lebih banyak, walaupun tidak berpengaruh nyata secara statistik.

Tabel 3. Pengaruh frekuensi aplikasi air cucian beras dan rendaman cangkang telur terhadap jumlah daun pertanaman

\begin{tabular}{|c|c|c|c|c|}
\hline \multirow[t]{3}{*}{ Perlakuan } & \multicolumn{4}{|c|}{ jumlah daun/tanaman } \\
\hline & $42 \mathrm{HST}$ & 56 HST & 70 HST & 84 HST \\
\hline & \multicolumn{4}{|c|}{--helai-- } \\
\hline A: kontrol (tanpa aplikasi) & $4,80 a$ & $5,33 a$ & $5,60 a$ & $5,06 a$ \\
\hline B: pupuk daun lengkap (Gandasil D) 10 hari satu kali & $5,33 a$ & $5,80 a$ & $6,26 a$ & $5,86 a$ \\
\hline C: aplikasi air cucian beras 3 hari satu kali & $5,40 a$ & $5,80 a$ & $6,26 a$ & $6,80 \mathrm{a}$ \\
\hline D: aplikasi air cucian beras 5 hari satu kali & $5,47 a$ & $6,00 a$ & $6,06 a$ & $6,26 a$ \\
\hline E: aplikasi air cucian beras 7 hari satu kali & $4,67 a$ & $5,07 a$ & $5,13 a$ & $5,53 a$ \\
\hline F: aplikasi air rendaman cangkang telur 3 hari satu kali & 5,13a & $5,27 a$ & $5,66 a$ & $5,46 a$ \\
\hline G: aplikasi air rendaman cangkang telur 5 hari satu kali & $5,33 a$ & $5,53 a$ & $5,53 a$ & $5,53 a$ \\
\hline H: aplikasi air rendaman cangkang telur 7 hari satu kali & $5,00 a$ & $5,40 a$ & $5,33 a$ & $4,95 a$ \\
\hline
\end{tabular}

Keterangan : Angka-angka yang diikuti ol eh huruf yang sama tidak berbeda nyata menurut uji Jarak Berganda Duncan pada taraf $5 \%$

Grafik luas daun pada berbagai perlakuan ditampilkan pada Gambar 2. Frekuensi aplikasi air cucian beras dan rendaman cangkang telur tidak berpengaruh nyata berdasarkan hasil analisis varians terhadap luas daun. Perlakuan aplikasi pupuk daun 10 hari satu kali, air cucian beras 3, 5, 7 hari satu kali dan aplikasi air rendaman cangkang telur 3, 5, 7 hari satu kali tidak berbeda nyata dengan control atau tanpa aplikasi pupuk . Walaupun demikian terlihat nilai angka rata-rata luas daun lebih tinggi pada perlakuan aplikasi air cucian beras 3 hari satu kali dengan luas daun $18 \mathrm{~cm}^{2}$.

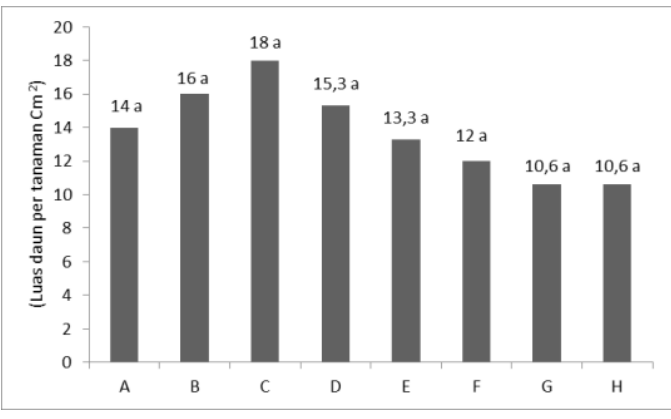

Gambar 2. Grafik luas daun pada berbagai jenis perlakuan

Grafik pengaruh frekuensi aplikasi air cucian beras dan rendaman cangkang telur terhadap bobot brangkasan per tanaman ditampilkan pada Gambar 3. 


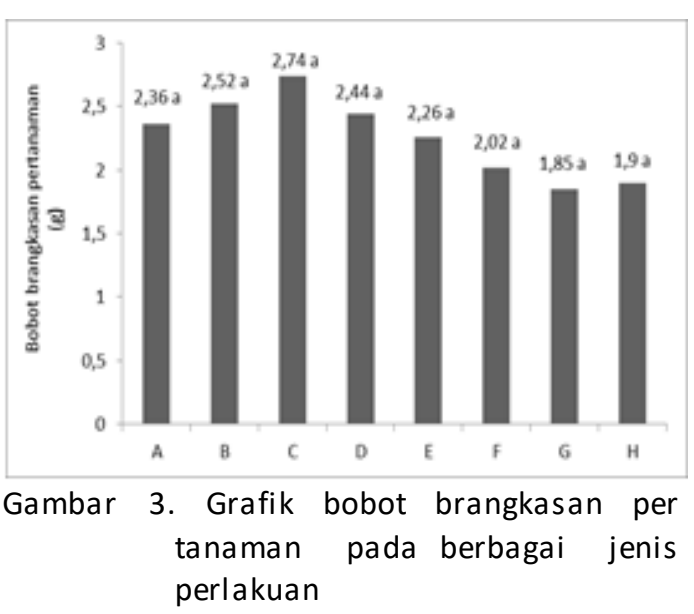

Secara umum dapat dikemukakan angka rata-rata bobot brangkasan lebih tinggi pada perlakuan aplikasi air cucian beras 3 hari satu kali, meskipun hasil uji Duncan tidak berbeda nyata. Hal-hal yang menyebabkan perlakuan tidak berpengaruh nyata secara statistik yaitu:

1. Bibit anggrek sampai dengan umur 84 hari setelah tanam (HST), masih berada dalam fase pertumbuhann vegetative lambat. Menurut Tirta (2006), pertumbuhan anggrek sangat lambat, sehingga membutuhkan waktu yang cukup lama untuk memperlihatkan gejala defisiensi. Selama fase ini merupakan fase inisiasi memerlukan suplai unsur hara dalam jumlah yang sedikit, seningga cukup dipenuhi oleh unsur harayang berasal dari media tanam. Media tanam yang dipakai pada penelitian ini yaitu media tanam yang berasal dari cacahan batang pakis. Menurut Setiawan (2003) media tanam pakis mempunyai daya mengikat air, aerasi dan drainasi yang baik, lapuk secara perlahanlahan, namun mengandung unsur hara yang sangat sedikit.

2. Aplikasi pupuk melalui daun, waktu penyemprotannya dilakukan pada siang hari, seharusnya pada sore dan malam hari, karena anggrek termasuk tanaman golongan Crassulacean Acid Metabolism (CAM). Menurut Salisburry dan Ross (1992), pada golongan CAM sifat stomata membuka pada malam dan menutup pada siang hari. Mekanisme CAM mengikat karbondioksiada pada malam hari ketika stomata membuka, kesempatan ini pula digunakan agar air dan unsur hara dapat masuk ke dalam stomata

3. Unsur hara yang berasal dari air cucian beras dan rendaman cangkang telur sangat lambat ketersediannya sehingga belum bisa diserap seluruhnya sampai dengan umur 84 HST. Hasil analisis menunjukkan kandungan nitrogen, fosfor, dll masih rendah. Pada semua perlakuan jumlah yang diaplikasikan sebanyak $450 \mathrm{ml}$. Jumlah kandungan masing masing dapat dilihat pada Tabel 5

4. Hasil analisis kandungan air cucian beras dan air rendaman cangkang telur menunjukkan bahwa air cucian beras mengandung $\mathrm{N}$ sebesar 0,29 \% (2900 ppm), Mg : 7.8 ppm, Fe tersedia : 1.68 ppm dan $\mathrm{Fe}$ total : 43.00 ppm,sedangkan pada air rendaman cangkang telur mengandung $\mathrm{P}$ total sebesar 54.04 ppm, K : 31.00 ppm dan $\mathrm{S}: 2446.81 \mathrm{ppm}$. Kandungan unsurnya jauh lebih rendah dengan aturan yang dibuat oleh Peraturan Mentri Pertanian (2019), standar mutu pupuk organik cair adalah $\mathrm{pH} 4$ sampai 8 , kadar total $\mathrm{N}, \mathrm{P}, \mathrm{K}<2,00 \%$, secara umum pupuk organik mengandung unsur $\mathrm{N}, \mathrm{P}, \mathrm{K}$ yang dibutuhkan tanaman dengan sejumlah nutrisi yang terdiri atas 1 sampai $7 \% \mathrm{~N}, 2$ sampai $12 \% \mathrm{P}$ dan 0 sampai $10 \% \mathrm{~K}$. 
Tabel 5 Ringkasan Hasil Analisis Air Cucian Air Beras*) dan Air Cangkang Telur ${ }^{*}$

\begin{tabular}{|c|c|c|c|c|c|c|c|c|}
\hline No & Parameter & Unit & $\begin{array}{l}\text { Cangkang } \\
\text { telur }\end{array}$ & $\begin{array}{l}\text { Kandunga } \\
\mathrm{n} \text { dalam } \\
40 \mathrm{ml}\end{array}$ & $\begin{array}{l}\text { Cucian } \\
\text { airberas }\end{array}$ & $\begin{array}{l}\text { Kandungan } \\
\text { dalam } 40 \mathrm{ml}\end{array}$ & Gandasil & $\begin{array}{c}\text { Kandungan } \\
\text { dalam } 40 \\
\mathrm{ml}\end{array}$ \\
\hline 1 & $\mathrm{~N}$ total & $\%$ & 0,22 & 0,99 & 0,29 & 1,305 & 20 & 90 \\
\hline 2 & P total & ppm & 54,04 & 0,02432 & 0,05 & 22,5 & 150 & 0,0675 \\
\hline 3 & $\mathrm{~K}$ total & ppm & 31,00 & 0,00003 & 0,01 & 0,000001 & 150 & 0,0675 \\
\hline 4 & $\mathrm{Ca}$ & $\mathrm{ppm}$ & 2,00 & 0,0009 & 1,65 & 0,000165 & & \\
\hline 5 & $\mathrm{Mg}$ & $\mathrm{ppm}$ & 0,00 & 0 & 7,8 & 0,00351 & & \\
\hline 6 & $S$ & $\mathrm{ppm}$ & 2446,81 & 110.107 & 0 & & & \\
\hline 7 & Fe ters edia & ppm & 0,50 & 0,00001 & 1,65 & 0,000743 & & \\
\hline 8 & Fe total & ppm & 7,00 & 0,00315 & 43,00 & 0,01935 & & \\
\hline \multirow[t]{2}{*}{9} & Tiamin B1 & $\mathrm{mg} / 10$ & & & & & & \\
\hline & & $0 \mathrm{~g}$ & 0,01 & 0,045 & 0,05 & 0,225 & & \\
\hline 10 & $\mathrm{pH}$ & - & 7,06 & & 4,11 & & & \\
\hline \multirow[t]{2}{*}{11} & Vitamin $\mathrm{K}$ & $\mathrm{mg} / 10$ & & & & & & \\
\hline & & $0 \mathrm{~g}$ & 2,01 & 9.045 & 0,00 & & & \\
\hline 12 & Pseudomonassp & & $<1 \times 10^{4}$ & & $<1 \times 10^{4}$ & & & \\
\hline
\end{tabular}

Keterangan : ${ }^{*}$ : Hasil pengujian di labolatorium International Center of Biodeversity and Biotechnol ogy (ICBB) Bogor

Penyebab sedikitnya kandungan unsur hara dalam air cucian beras dan cangkang telur disebabkan oleh kurangnya lama fermentasi dan fermentoryang dipakai EM4 $7 \mathrm{ml} \mathrm{l}^{-1}$. Menurut Fradiaz (1992) dalam Ariani Kasmiran (2011), bahwa lama fermentasi merupakan salah satu faktor yang harus diperhatikan.

Lama fermentasi yang singkat mengakibatkan terbatasnya kesempatan dari mikroorganisme untuk berkembang, sehingga komponen substrat yang dapat dirombak menjadi massa sel juga akan sedikit tetapi dengan waktu fermentasi yang lebih lama berarti memberi kesempatan bagi mikroorganisme untuk tumbuh dan berkembang dengan baik.

\section{SIMPULAN}

1. Air cucian beras dan air rendaman cangkang telur belum diketahui efektifitasnya terhadap peningkatan pertumbuhan fase seedling sampai dengan umur 84 hari setelah tanam.

2. Aplikasi air cucian beras dan air rendaman cangkang telur yang diaplikasikan pada 3,5 dan 7 hari sekali tidak menyebabkan peningkatan terhadap tinggi tanaman, jumlah daun, luas daun dan bobot brangkasan segar tanaman sampai umur 84 HST.

\section{UCAPAN TERIMAKASIH}

Ucapan terimakasih yang sebesar-besarnya disampaikan kepada Direktorat Riset dan Pengabdian Masyarakat Direktorat Jendral Penguatan Riset dan Pengembangan Kementrian Riset dan Teknologi Pendidikan Tinggi Republik Indonesia yang telah mendanai penelitian melalui skema Penelitian Terapan tahun anggaran 2017. Tidak lupa penulis juga ucapkan terimakasih kepada rektor Universitas Siliwangi, Ketua Lembaga Penelitian dan Pengabdian Masyarakat dan Pengendal ian Mutu Universitas Siliwangi, dan Dekan Fakultas Pertanian Universitas Siliwangi.

\section{DAFTAR PUSTAKA}

Akib, M. A., Setiawaty, H., \& Haniarti. (2014). Improving the Quality of "Leri 
" Rice Washing Waste by Different Period of Fermentation and Yeast Concentration as an Alternative Liquid Organic Fertilizer. International Journal of Agriculture System (IJAS), 2(2), 153-162.

Andalasari, T. D., Yafisham, \& Nuraini. (2014). Respon Pertumbuhan Anggrek Dendrobium Terhadap Jenis Media Tanam Dan Pupuk Daun Respon Pertumbuhan Anggrek Dendrobium Terhadap Jenis Media Tanam Dan Pupuk Daun. Jurnal Penelitian Pertanian Terapan, 14(1), 76-82. https://doi.org/10.1109/ICECCS.2001. 930181

Andalasari, Tri Dewi, Yafishan dan Nuraini (2015), Respon Pertumbuhan Anggrek Dendrobium Orhid to Growing Media and Fertilizers Leaves,Jurnal Pertanian terapan Vol 14 (3):167-1731

Badan Pusat Statistik. (2017). Statistik Tanaman Hias Indonesia. Jakarta.

Balai Penelitian Tanaman Hias. (2012). Budidaya anggrek Dendrobium. Balai Penelitian Tanaman Hias.

Citra Wulandari, G. M. Muhartini, S., \& Trisnowati, S. (2012). Pengaruh Air Cucian Beras Merah dan Beras Putih Terhadap Pertumbuhan dan Hasil Selada (Lactuca sativa L.). Vegetalika, 1(2), 24-35.

Dewi, S., \& Setiawati, A. (2010). Pengaruh Waktu dan Frekensi Aplikasi Pupuk Daun Terhadap Pertumbuhan dan Pembungaan Anggrek Dendrobium "Tong Chai Gold." Jurnal Hortikultura Indonesia, 1(2), 96-103. Retrieved from download.portalgaruda.org/article.ph p?...Pengaruh Waktu dan Frekuensi...\%0A1.\%09\%0A

Dwiyani, R. (2012). Respon Pertumbuhan
Bibit Anggrek Dendrobium sp . pada Saat Aklimatisasi terhadap Beragam Frekuensi. Agrotrop, 2(2), 171-175.

Gongruttananun, N. (2011). Effects of using eggshell waste as a calcium source in the diet of Rhode Island Red roosters on semen quality, gonadal development, plasma calcium and bone status. Kasetsart Journal Natural Science, 45(3), 413-421. https://doi.org/10.1007/978-981-100036-2_26

Hartati, S., Budiyono, A., \& Cahyono, O. (2014). Peningkatan Ragam Genetik Anggrek Dendrobium spp Melalui Hibridisasi untuk Mendukung Perkembangan Anggrek di Indonesia. Caraka Tani, XXIX(2), 101-105.

Menteri Pertanian Republik Indonesia, Keputusan Menteri Pertanian Republik Indonesia No 261/kpts/SR.310/m/4/2019, Persyaratan Teknik Minimal, Pupuk Organik, Pupuk Hayati dan Pembenah Tanah.

Nikose, H. S. (2015). Egg Shell and BioWaste Manure. International Journal Of Scientific \& Engineering Research, 6(6), 1680-1685.

Novianto. (2012). Prospek Pengembangan Usaha Anggrek Berbasis Sumberdaya Lokal. In Prosiding Seminar Nasional Anggrek 2012 (pp. 11-20). 2012: Balai Penelitian Tanaman Hias.

Ramadhan, M. F., Hidayat, C., \& Hasani, S. (2015). Pengaruh Aplikasi Ragam Bahan Organik dan FMA terhadap Pertumbuhan dan Hasil Tanaman Cabai (Capsicum annum L.) Varietas Landung pada Tanah Pasca Galian C. Jurnal Agro, II(2). https://doi.org/10.15575/438

Setiawan. (2003). Merawat Phalaenopsis. 
PT Penebar Swadaya. Jakarta

Salisbury, Frank B., dan Cleon w Ross, 1992. Fisiologi Tumbuhan . Jilid II ITB Bandung

Sari, D. N., Zairin, T., \& Yunita. (2015). The Influence of Coconut Water and Activated Charcoal in MS Medium on In Vitro Callus Regeneration of Dendrobium sp . Cultivar Bertha Chong Orchids. Jurnal Natural, 15(1), 1-4.

Tirta, I. G. (2006). The effects of planting media and leaf fertilizers on the growth of jamrud orchid (Dendrobium macrophyllum A. Rich.). Biodiversitas, Journal of Biological Diversity, 7(1), 81-84.

https://doi.org/10.13057/biodiv/d070 120

Wardiah, L., \& Rahmatan, H. (2014). Potensi limbah air cucian beras sebagai pupuk organik cair pada pertumbuhan pakchoy (Brassica rapa) L. Jurnal Biologi Edukasi, 6(1), 34-38. 